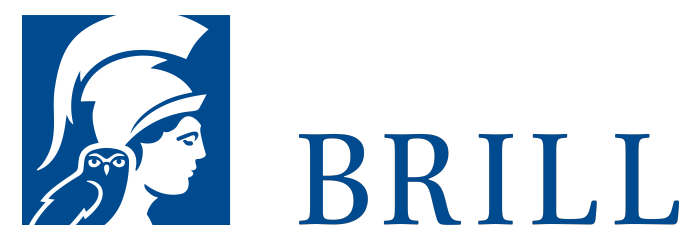

\title{
Herausforderung Islam
}

\section{Christliche Annäherungen}

Author: Klaus von Stosch

Gehört der Islam zu Europa? Wie soll sich der Westen zum Islam verhalten? Nicht nur der Westen, auch die christliche Theologie tut sich schwer mit dem Islam. Sie schwankt zwischen einem rein religionskundlichen Blick von außen und einer sich rechtfertigenden Abwehrhaltung, die im Grunde nur die Überlegenheit des eigenen Glaubens beweisen will. Beide Alternativen sind verfehlt. Christliche Theologie ist vielmehr aufgerufen, ehrlich herauszufinden, ob und unter welchen Bedingungen sie den muslimischen Glauben würdigen kann, ohne ihre eigenen Wahrheiten zu verraten. Wie und unter welchen Umständen kann beispielsweise die Rezitation des Korans auch aus christlicher Sicht als Wort Gottes verstanden werden, und können auch Christen in Muhammed einen Menschen sehen, der in den Spuren der Propheten wandelt? Das vorliegende Buch will genau das leisten: Eine christliche Würdigung des Islams, die gerade die Verschiedenheit beider Religionen als Wert zu entdecken vermag. Es möchte so zu einer Begegnung mit dem Islam einladen, die nicht nur Verstehen, sondern Liebe will - einer Begegnung, die uns hilft, uns selbst im Anderen neu zu entdecken und tiefer zu verstehen.

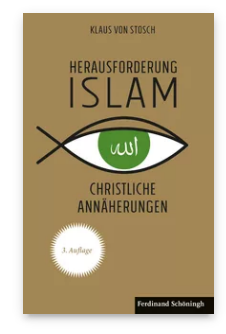

Pages: 208

Seiten

Language:

German

Subjects:

Comparative

Religion \&

Religious

Studies,

Religious

Studies

Publisher: Brill |

Schöningh

E-Book (PDF)

Released online:

o1 Sep 2017

ISBN: 978-3-

657-78783-8

List price

Paperback

Publication date:

15 Feb 2019

ISBN: 978-3-

5०6-78о2о-1

List price 
Klaus von Stosch ist Professor für Katholische Theologie (Systematische Theologie) und ihre Didaktik und Vorsitzender des Zentrums für Komparative Theologie und Kulturwissenschaft an der Universität Paderborn.

For more information see brill.com

$$
\begin{aligned}
& \text { Order information: Order online at brill.com } \\
& +4433 \circ 333 \text { o049 | customerservices@brill.com } \\
& \text { Submission information: brill.com/authors }
\end{aligned}
$$

Titles published by Brill | Fink, Brill | mentis or Brill | Schöningh: +49(o)71 5413279216 | brill@brocom.de 